\title{
What will 'taking back control' mean for social policy in the UK? Brexit, public services and social rights
}

\author{
Kitty Stewart, Kerris Cooper and Isabel Shutes
}

London School of Economics and Political Science

April 2020

\section{Abstract}

While social policy falls predominantly under national rather than European Union (EU) jurisdiction, there are nonetheless multiple ways in which social policy and social outcomes in EU member states have been affected by EU membership. This paper draws on existing evidence and analysis to review the consequences for UK social policy of the decision to leave the EU. We focus predominantly on the implications of the British Government's pledge to 'take back control' of money, borders and laws. Our conclusion is that Brexit is likely to have negative effects on the quality of public services and, for some groups in particular, social rights, and that these effects are likely to be greater the more distant the future trading and wider relationships between the UK and the EU27.

Keywords: Brexit, EU, social policy, welfare state, public services, social rights. 


\section{Introduction}

What impact will the UK's decision to leave the European Union (EU) have on social policy? The most obvious implications are those facing citizens travelling between the UK and the remaining 27 member states for work, play or study, and needing to access social security or healthcare. But Brexit is also likely to have long-term consequences for social policy and social outcomes within the UK, while the absence of the UK from EU decision-making may ultimately affect social policy in the EU. This paper concentrates on the implications for the UK. Drawing on existing evidence and analysis, it considers how public services, living standards and social and employment rights have been affected by EU membership, and hence the likely implications of the decision to leave. (For discussion of the implications of Brexit for social policy in the EU, see Hantrais, 2019).

While the social dimension of the EU has grown in scope, most aspects of social policy, including social security, health care and education, remain solidly under national jurisdiction, arguably in some part due to UK resistance to deeper social integration (Hantrais, 2019). The most direct way in which social policy is affected by EU membership is through the Charter of Fundamental Rights, which in addition to employment protection covers work-family balance and rights to social and housing assistance, protection and care of children and older people and preventive health care (Hantrais, 2007). There have been extensive efforts to monitor and coordinate wider social progress through European observatories and networks and, from 2006, through the Open Method of 
Coordination but these did not require or create policy convergence (Cantillon et al, 2018; Hantrais, 2019). However, while the implications of Brexit for UK social policy include the potential loss of the Charter, they go well beyond this.

The paper takes as an organizing framework the goals encapsulated in the referendum slogan of the Vote Leave campaign, a slogan subsequently adopted by the UK government: "taking back control of our borders, money and laws" (HM Government 2018a). These are the outcomes that the UK public were promised. What will they mean in practice for the substance of the policies that affect day-to-day life? We start by considering the social policy implications of ending free movement (taking back control of borders). We then look at what withdrawal will mean for the size of the fiscal envelope (money). Last, we explore the consequences of gaining control over rules on human and workers' rights (laws).

\section{Taking back control of borders: An end to free movement}

A fall in EU migration looks inevitable as a result of Brexit. Even before any rule changes, net EU migration fell sharply from over 200,000 in the year ending early 2016 to 50,000 in late 2019, the lowest level since 2004 (ONS, 2020). From January 2021 existing overall caps on skilled migrants will be lifted but a new points-based immigration system will govern entry for EU and non-EU citizens alike. New arrivals will need to speak English and to have a job offer in a skilled profession at a minimum salary level $(£ 25,600)$, with some flexibility on salary for those in shortage occupations or with certain $\mathrm{PhD}$ qualifications (UK 
Government, 2020). The social policy implications of lower numbers of EU migrants depends on both their contribution to public service delivery and on the pressure they place on service use.

\section{Net contributors or net beneficiaries?}

Despite perceptions of 'welfare tourism' - that EU migrants move to the UK to take advantage of benefits or public services - EU citizens have only ever had full access to social security provision in other member states if they are workers or family members of workers. In practice, the weight of evidence strongly suggests that migrants from European Economic Area (EEA) countries to the UK pay more in taxes than UK-born residents, and more than they receive in benefits or social provision. This is partly because EEA migrants tend to be younger and more likely to be working than the UK-born population.

Looking at taxation and cash benefits only, official UK government data shows EEA migrants making a net fiscal contribution, although with variation by country of origin (European Citizen Action Service, 2014). On average, EEA migrants are estimated to pay around $£ 2,300$ more in tax annually than the average adult resident, reflecting both high employment and relatively high earnings (MAC, 2018).

There is less data on service use (housing, health, education and public goods), but modelling based on a range of assumptions tells a positive story. EEA migrants arriving between 1995 and 2011 are estimated to have made a net positive contribution $10 \%$ larger than that of the UK-born population, although 
non-EEA migrants made a negative contribution (Dustmann and Frattini, 2014). Rowthorn (2014) challenges some of Dustmann and Frattini's assumptions - for example, the allocation of no cost to migrants for energy, transport and communications, on grounds that these are public goods - yet also concludes that recent EEA migrants have either paid their way or generated a modest fiscal surplus.

A comprehensive picture would need calculations across the life-course. These would be expected to present a more positive picture than static models, in part because those migrating as adults have had education and childhood health costs covered elsewhere. Migrants arriving between 1995 and 2011 are estimated to have imported human capital that would have cost $£ 14$ billion if produced in the UK education system (Dustmann and Frattini, 2014). In addition, some migrants may return to their original country in retirement, saving health costs for the UK. The MAC's dynamic model estimates that the 515,000 migrants who arrived in 2016 will make a discounted net contribution of $£ 26.9$ billion in their lifetime, or $£ 78,000$ per capita (MAC, 2018).

\section{Service use}

EEA migrants may make a net contribution overall and yet still create pressures on particular services or areas. In terms of health, there is some limited evidence to this effect. Probably because they are relatively young and healthy, migrants appear around half as likely to have a hospital admission as the general population (MAC, 2018), though birth rates are higher among EU migrants than the UK-born, making maternity services an exception (Steventon and Bardsley, 
2011). Having more migrants in the local population has been found to reduce waiting times for health services (Guintella et al, 2015), and while migrants are slightly more likely to use GP services than the UK-born population (Wadsworth, 2012), there is little evidence of any relationship between local migrant share and GP satisfaction beyond a positive impact of EU13+ migrants (MAC, 2018). However, the effect on waiting times identified by Guintella et al is largest in the least deprived areas, and a short-run negative impact was identified following the 2004 EU enlargement: higher immigration was found to increase the average waiting time in deprived areas outside London. Particularly in the context of the squeeze in UK health spending relative to need since 2010 (Vizard and Obolenskaya, 2015), migrant populations may thus be felt in some disadvantaged areas as contributing to excess pressure on services.

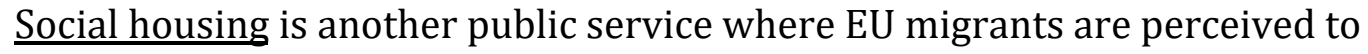
increase pressure on scarce resources. Social housing in the UK tends to be considerably cheaper than renting privately and has more stable tenures, making it a valuable and highly rationed good. A significant share of white Britons report feeling discriminated against by social landlords in relation to other ethnic groups (Battiston et al, 2014). In practice, there is no evidence of migrants being given priority (Vargas-Silva, 2017), but different rules apply in different areas and are not always transparent, and some groups of migrants may have characteristics that confer priority, feeding misperceptions (Rutter and Latorre, 2009). Even without discrimination in favour of migrants, immigration will reduce access to social housing for the UK-born in a context in which supply is inflexible. EEA migrants comprised only $3.4 \%$ of all social housing residents in 
2017, but the share of new lettings going to UK-born tenants fell from $95 \%$ in 2007 to $92 \%$ in 2016, with a rising share going to EU migrants (MAC, 2018). Particularly in areas in which EU migration is very concentrated, this does suggest more competition and a reduced likelihood of a tenancy for UK-born families on the housing waiting list.

EEA migrants are more likely than other UK residents to have children of schoolage, and have higher birth rates, as noted, so EU immigration has created additional demand for school places. But this does not mean migrant pupils impede either schooling options or outcomes for other pupils. No statistically significant relationship has been found between the migrant share in a local education authority and the percentage of parents receiving their first preference of school (MAC, 2018). Studies have also found either no effect or a positive effect of the number of children with English as an Additional Language (EAL) on educational outcomes for non-EAL children (Geay et al, 2013; MAC, 2018).

\section{Service delivery}

The effects of lower EU migration on the ability to deliver public services are likely to be much more substantial than any impact on demand. This is not the case in all sectors: in primary and secondary schools, EEA born teachers make up just $3 \%$ of the teaching workforce compared to $8 \%$ of pupils who have at least one EEA-born parent (MAC, 2018). But it is relevant to housing, where insufficient new construction to replace sales of existing stock appears to be the main reason for the falling probability of living in social housing for UK-born 
households (Vargas-Silva et al, 2016). Some 18\% of the home-building workforce comes from an EU country, including 50\% of the workforce in London (Home Building Federation, 2017). Many of these workers are unlikely to fulfil the criteria for entry under the new points-based system.

Lower EEA immigration could also have significant effects on the workforce in health and social care. EU nationals make up 5\% of NHS workers in NHS England, including around $10 \%$ of doctors and higher percentages for some specialisms (Hervey and McCloskley, 2018). In 2015 almost a third of newly registered nurses had trained in the EEA (Dayan, 2017). This is in a context of cuts in UK funding for training and growing staff shortages: one in ten nursing posts and more than 50,000 clinical roles were estimated to be unfilled at the time of the referendum (NAO, 2016; Simpkin and Mossialos, 2017). There are also shortages in social care, where EU nationals make up 7\% of the total workforce, rising to 13\% in London (DoH, 2017). Projections for 2025/26 indicate shortages of between 20,000 and 50,000 nurses and 70,000 careworkers if EU migration falls substantially (Dayan, 2017).

The points-based system will allow the continued arrival of doctors with job offers, and of nurses if nursing is listed as a 'shortage occupation' and thus exempt from minimum salary thresholds. The theory is that workforce needs can be met while allowing more control over migration than free movement allows. But the strategy relies on skilled migrants continuing to see the UK as an attractive destination: a weaker economy, a depreciated currency and 
perceptions of a less tolerant society may work against this, as the fall in net EU migration to date may indicate.

An alternative longer-term response is for the UK to train and employ more UKborn workers. This offers potential advantages to young UK citizens but would require substantial investment, both in training and in higher wages, in a context of tightly stretched resources. It costs an estimated $£ 200,000$ to train a doctor in the UK (Simpkin and Mossialos, 2017); currently the NHS reaps the benefits of investment made by other countries. In social care, training costs are lower, but the sector faces competition from other low-skilled sectors like retail. A wage increase would likely be required, beyond the National Minimum Wage, carrying significant funding implications in a sector where wages form $50 \%$ of costs (Dayan, 2017).

\section{Taking back control of money: The fiscal consequences of Brexit}

The challenges arising from reduced EU migration could be much mitigated by increased public spending. Leaving the EU should give the UK Treasury a 'Brexit dividend' - or so it has been claimed. ${ }^{1}$ Taking back control of the money spent on EU membership fees was a key plank of the referendum campaign, with the controversial 'Brexit bus' promising millions in increased investment for the NHS. ${ }^{2}$ In practice, however, such savings are projected to be swamped by the losses from slower economic growth. 
Uncertainty about the medium-term economic implications of Brexit remains high, and not only because future trading relationships are still to be negotiated, nor because of the additional economic challenges arising from COVID-19. Leaving a major trading bloc is almost entirely without precedent, and Brexit involves simultaneous shocks to trade, migration, financial services, regional aid, industrial strategy and more (Oxrep, 2017). Nonetheless, there is strong consensus on two points: that the impact on GDP growth of any Brexit scenario will be negative compared to remaining in the $\mathrm{EU}$, and that the effects will be larger for 'harder' forms of Brexit (Dhingra et al, 2016; Sampson, 2017; HM Government, 2018b). UK government projections prior to the COVID-19 crisis fell broadly in the middle of a range of available estimates: a $1.6 \%$ reduction in income per capita 15 years on if the UK left the EU but followed the Norway model (EEA membership); a 4.8\% reduction under a negotiated Free Trade Arrangement (FTA) (Prime Minister Boris Johnson's stated goal); and 7.7\% under World Trade Organisation rules (the 'no deal' scenario) (House of Commons Exiting the EU Committee, 2018).

Economic models are scarcely infallible, and projections for the immediate economic impact of a Leave vote were overly pessimistic (Singham and Tylecote, 2018). Yet forecasts of the impact through to the end of 2018 were very close to the mark, with predicted effects simply coming later than anticipated (Schulz, 2018; Smith, 2018). If negative economic effects do play out, they carry implications both for average living standards and for public spending. Projections by the independent Office for Budget Responsibility (prior to the COVID pandemic) anticipated a hit to public revenue of about $£ 15$ billion a year 
by the early 2020s; double in the event of no deal (OBR, 2018; OBR, 2019). Looking further ahead, the government projected annual borrowing in 2033-34 at around $£ 20$ billion higher than the status quo for the EEA model, $£ 55$ billion higher for the FTA model and $£ 80$ billion for WTO (House of Commons Exiting the EU Committee, 2018). These estimates include budget savings from EU contributions - roughly $£ 8$ billion (below 1\% of GDP) after accounting for the budget rebate and existing EU spending in the UK (Levell and Stoye, 2018).

The impact of the COVID-19 response dwarfs these numbers in the short-term. UK borrowing for 2020-21 has been projected at $£ 218$ billion higher than previously anticipated, with debt remaining $10 \%$ of GDP higher than forecast in 2024-25 (OBR, 2020). Yet the underlying economic challenges posed by leaving the single market and customs union are not changed by the COVID response; rather they will now be added to an already exceptionally difficult fiscal position. Leaving the EU will mean less money for public spending rather than more, at a time when the UK can least afford it.

\section{Taking back control of laws: human and social rights}

After Brexit, if the UK leaves the single market, it will no longer be subject to the Charter of Fundamental Rights enforced by the Court of Justice of the European Union (CJEU). This can be seen as a key aspect of 'taking back control' of decision-making relevant to social policy. Currently, EU law takes supremacy over any conflicting laws of member states and also confers freedoms and rights on EU citizens which cover social and workers' rights, citizens' rights, justice, 
dignity, discrimination and political freedoms (see Bojarski et al, 2014 for a full summary).

The relationship between EU and UK law on rights has been dynamic and interactive, not a one-way street: at times the UK has made progressive changes that have subsequently been incorporated into EU law, while in other cases the EU has pushed the UK forward (Fredman et al, 2018). For example, the UK was ahead of the EU in legislating against race and disability discrimination, while EU law has had greatest impact in relation to sex discrimination and work-life balance legislation. Important EU-driven protections for precarious workers in the form of directives covering part-time, fixed-term and agency workers may never have been gained under UK law given the backdrop of zero hours contracts (Fredman et al, 2018). The Working Time Directive, which includes rights to rest, maximum working hours and protection for night workers, was implemented late in the UK and after considerable resistance, with numerous challenges from the CJEU due to the government's minimalist implementation (Ford, 2016). On the other hand, there are areas where UK provision currently exceeds EU minimum standards, including entitlement to annual leave and the right to flexible working.

Outside the single market, the UK will remain subject to the European Convention on Human Rights; this is part of international not EU law, with rights and obligations enforced through the domestic courts and the European Court of Human Rights, not the CJEU (Equality and Human Rights Commission, 2017). This covers civil and political but not social or economic rights. The European 
Social Charter (a Council of Europe treaty) will also still apply, and does include social rights, but has no mechanism for judicial enforcement. Without the Charter of Fundamental Rights, it is argued that the UK will be left with a weakening of equality protection and important gaps in human rights protection, including the free-standing right to non-discrimination, the rights of the child, the right to dignity and the right to health (Coppel, 2018; Roderick and Pollock, 2017). The UK Equality Acts of 2006 and 2010 provide some protection, including against discrimination, but these rights are not constitutionally protected and could be amended at any time. It will also be harder for individuals to seek legal redress when rights are violated, as EU law played an important remedial role with stronge mechansims for enforcement (Coppel, 2018; Harvey, 2018).

In practice, the result may be downward pressure on employment protection in particular, with greatest impact on workers in more precarious employment. This will disproportionately affect women, who are more likely to work parttime and have temporary contracts, in addition to the potential threat to rights gained for pregnant workers and in relation to sex discrimination law (TUC, 2016; Mott et al, 2018). Concerns have also been raised about the loss of protections gained from the EU for LGBT+ workers and workers with disabilities (Roache, 2018a,b). An enhancement of rights in response to greater power is of course possible but seems unlikely, not only because of the UK's track record, but also because many EU directives explicitly provide a floor and not a ceiling; stronger protection has always been possible (Ford, 2016). There are however 
some methods of pursuring equality goals that are currently restricted, for example affirmative action (Fredman et al, 2018).

Greater freedom for the UK in relation to workers' rights can be seen as restoring democractic power to Westminster: Britain will no longer have legislation imposed by Brussels that British voters would not have supported. However, the context facing the UK makes it plausible that employment rights may fall subject to wider economic priorities. Employment deregulation could mitigate some of the negative economic effects discussed earlier while also helping to attract foreign investment to a UK outside the EU. Workers' rights could also be on the table during trade negotiations: matching EU employment protection will very likely be a requirement of ongoing close trade relations with the EU (Harvey, 2018; O'Cinneide, 2018), but if such an agreement is not reached, the UK may prioritise commercial interests and deregulation in attempts to secure trade deals with other countries (Harrison et al, 2017). If rights legislation becomes a bargaining chip in this way, it is questionable how far UK voters will be gaining greater control.

\section{Conclusions}

Most aspects of social policy provision remain under national, not EU jurisdiction, and on the surface, it may seem that the most serious implications of Brexit for social policy are those affecting the rights to social security and healthcare of those travelling across the UK-EU border to study, work or retire. Yet EU membership has improved social policy provision for UK citizens in 
several important ways. One key mechanism is indirect: the benefits of EU membership for the economy have meant more money - higher living standards and greater possibilities for public spending. In addition, the free movement of workers has allowed public services in Britain to enjoy an inflow of skilled labour to fill workforce gaps, most notably in health, social care and construction. EU membership has also facilitated participation in coordinating mechanisms that have, among other things, improved access to medicines, enhanced research collaborations and increased the effectiveness of policing. And membership has ensured that UK workers have been beneficiaries of coordinated action to improve employment rights and prevent a competitive 'race to the bottom' to secure external investment.

Have there been downsides? Regaining greater control over borders, money and laws have been repeatedly identified in the UK as arguments in favour of leaving the EU. In terms of borders, some communities may have experienced the arrival of large numbers of migrants from other parts of Europe as unsettling and may have perceived a link between immigration and longer waiting lists. But the evidence points to negligible objective impact of EEA immigration either on employment and wages, or on access to services including health and housing, and shows EEA migrants making a net contribution to the exchequer. In terms of money, the costs of EU membership have been shown to be far outweighed by the benefits to the economy; there will be no 'Brexit dividend' to allocate.

It is in terms of laws that the arguments for Brexit may be strongest: there are examples of the UK being forced by EU requirements into actions that it would 
not otherwise have taken, for example in relation to aspects of employment protection. It may be said that Brexit offers genuinely greater national democratic control in this regard - the ability to become a lower-tax, lowerregulation economy, if that is what UK voters want. Yet decisions about workers' rights may very well end up being taken behind closed doors as part of complex trade negotiations - not obviously more democratic than being taken in Brussels. It is also far from clear that the ability to choose fewer rights at work were among the goals of those voting to leave. They were certainly never put forward by Leave campaigners as examples of what 'taking back control' could deliver.

\section{References}

Battiston, D, R Dickens, R, A Manning and J Wadsworth (2014) 'Immigration and the Access to Social Housing in the UK' CEP Discussion Paper No 1264, London: Centre for Economic Performance.

Bojarski, L., Hofbauer, J. and Mileszyk, N. (eds) (2014) The European Charter of Fundamental Rights as a Living Instrument: Guidelines for Civil Society, RomeWarsaw-Vienna: CFREU.

Cantillon, B, T Goedemé and J Hills (2018) 'Introduction,' in Decent Incomes for All: Improving Policies in Europe. Oxford: Oxford University Press.

Coppel, J. QC (2018) 'Legal opinion on European Union (Withdrawal) Bill - E.U. Charter of Fundamental Rights,' commissioned by the Equality and Human Rights 
Commission, available at

https://www.equalityhumanrights.com/sites/default/files/eu-withdrawal-billlegal-advice-jason-coppel-qc.pdf.

Dayan, M. (2017) 'General Election 2017: Getting a Brexit deal that works for the NHS,' Nuffield Trust Briefing. London: The Nuffield Trust.

Department of Health [DoH] (2017) Evidence on EEA nationals working within the health and care system, focusing on England. Written response to call for evidence by the Migration Advisory Committee. November 2017.

Dhingra, S, G Ottaviano, T Sampson and J Van Reenen (2016) 'The consequences of Brexit for UK trade and living standards,' CEP Brexit Analysis No 2, London: Centre for Economic Performance.

Dustmann, C. and Frattini, T. (2014) 'The fiscal effects of immigration to the UK', The Economic Journal 124 (November), F593-F643.

Equality and Human Rights Commission (2017) ‘What does Brexit mean for equality and human rights in the UK?' available at https://www.equalityhumanrights.com/en/our-human-rights-work/whatdoes-brexit-mean-equality-and-human-rights-uk.

European Citizen Action Service (2014) Fiscal impact of EU migrants in Austria, Germant, the Netherlands and the UK, Brussels: ECAS. 
Ford, M. QC (2016) 'Workers' rights from Europe: the impact of Brexit, independent legal opinion commissioned by the Trades Union Congress,' available at https://www.tuc.org.uk/research-analysis/reports/workers\%E2\%80\%99rights-europe-impact-brexit.

Fredman, S., Young, A. and Campbell, M. (2018) 'The Continuing Impact of Brexit on Equality Rights,' The UK in a Changing Europe available at $\underline{\text { http://ukandeu.ac.uk/research-papers/the-continuing-impact-of-brexit-on- }}$ equality-rights/.

Geay, C., McNally, S and Telhaj, S. (2013) 'Non-native speakers of English in the classroom: what are the effects on pupil performance?' Economic Journal, 123 (570). F281-F307.

Guintella, O., Nicodemo, C. and Silva, C. (2015) 'The effects of immigration on NHS waiting times', IZA Discussion Paper No. 9351.

Hantrais, L (2007) Social Policy in the European Union, Third Edition. Basingstoke: Palgrave Macmillan.

Hantrais, L (2019) What Brexit means for EU and UK Social Policy, Policy Press Shorts, Bristol: The Policy Press.

Harrison, J., Campling, L., Richardson, B., Smith, A. and Barbu, M. (2017) 'Taking labour rights seriously in post-Brexit UK trade agreements: protect, promote, empower', CSGR Working Paper (284/17), Coventry: University of Warwick. 
Harvey, C. (2018) 'Thinking about human rights and Brexit', ?UK in a Changing Europe, accessed on $13^{\text {th }}$ February 2019 at https://ukandeu.ac.uk/thinking-abouthuman-rights-and-brexit/

HM Government (2018a) EU Exit: Taking back control of our borders, money and laws while protecting our economy, security and Union, Cm 9741, London: HMSO.

HM Government (2018b) Long Term Economic Analysis, November 2018.

Hervey, T. and McCloskley, S. (2018) 'Staff', in Barnard, C. (ed), Brexit and the NHS, UK in a Changing Europe.

Home Building Federation (2017) Home Building Workforce Census 2017, London: Home Building Federation.

House of Commons Exiting the European Union Committee (2018) EU Exit Analysis Cross Whitehall Briefing January 2018.

Levell, P. and Stoye, G. (2018) 'A 'Brexit dividend' to spend on the NHS?' IFS Observations, https://www.ifs.org.uk/publications/10354

MAC (2018) EEA Migration in the UK: Final Report, London: Migration Advisory Committee.

Mott, H., Fontana, M., Sephenson, M. and De Henau, J. (2018) ‘Exploring the Economic Impact of Brexit on Women', London: Women's Budget Group and the Fawcett Society. 
National Audit Office [NAO] (2016) Managing the supply of NHS clinical staff in England, HC736, Session 2015-16.

OBR (2018) Brexit and the OBR's forecasts, London: Office for Budget Responsibility.

OBR (2019) Fiscal risks report, London: Office for Budget Responsibility.

OBR (2020) OBR Coronavirus Reference Scenario, 14 April 2020, London: Office for Budget Responsibility.

O’Cinneide, C. (2018), 'Brexit and Human Rights', Brexit: The International Legal Implications, Paper No. 16, Canada: Centre for International Governance Innovation.

ONS (2020) Migration Statistics Quarterly Report: February 2020. London: Office for National Statistics.

Oxrep (2017) 'The economics of Brexit: what is at stake?' Editorial, Oxford Review of Economic Policy, 33(S1):S1-S3.

Roache, Q. (2018a) 'Brexit and LGBT+ Rights,' Trades Union Congress, available at https://www.tuc.org.uk/research-analysis/reports/brexit-and-lgbt-rights

Roache, Q. (2018b) 'Brexit and Disability Rights,' Trades Union Congress, available at https://www.tuc.org.uk/research-analysis/reports/brexit-and-disability-rights 
Roderick, P and Pollock, A. (2017) 'Brexit's Great Repeal Bill will ace the right to health', The British Medical Journal, BMJ 2017 (357): j2013.

Rowthorn, R. (2014) 'A note on Dustmann and Frattini's estimates of the fiscal impact of UK immigration,' http://www.civitas.org.uk/pdf/rowthorndustmannfrattini.pdf

Rutter, J. and Latorre, M. (2009) 'Social housing allocation and immigrant communities', Manchester: Equality and Human Rights Commission.

Sampson, T. (2017) 'Brexit: The Economics of International Disintegration,' Journal of Economic Perspectives, 31 (4), pp.163-184.

Schulz, C. (2018) 'UK Outlook,' Chapter 2 in The IFS Green Budget, October 2018, London: Institute for Fiscal Studies.

Simpkin, V. and Mossialos, E. (2017) 'Brexit and the NHS: challenges, uncertainties and opportunities', Health Policy. 121(5), 477-480.

Singham, S. and Tylecote, R. (2018) Plan At: Creating a prosperous post-Brexit UK. London: Institute of Economic Affairs.

Smith, D. (2018) 'A good year for the forecasters,' David Smith's EconomicsUK.com, 30 December 2018, http://www.economicsuk.com/blog/002294.html

Steventon, A. and Bardsley, M. (2011) 'Use of secondary care in England by international immigrants'. Journal of Health Services Research \& Policy 16(2), 90-94. 
Trades Union Congress (2016) 'Women workers' rights and the risks of Brexit,' available at https://www.tuc.org.uk/research-analysis/reports/womenworkers $\%$ E2\%80\%99-rights-and-risks-brexit

UK Government (2020) The UK's points-based immigration system: policy statement.

Vargas-Silva, C. (2017) 'Briefing: Migrants and Housing in the UK: Experiences and Impacts,' University of Oxford: The Migration Observatory.

Vargas-Silva, C., Markaki, Y. and Sumption, M. (2016) The impacts of international migration on poverty in the UK, York: Joseph Rowntree Foundation.

Vizard, P and Obolenskaya, P. (2015) ‘The Coalition’s Record on Health: Policy, Spending and Outcomes 2010-2015,' Social Policy in a Cold Climate Working paper 16.

Wadsworth, J. (2012) ‘Musn't Grumble. Immigration, Health and Health Service Use in the UK and Germany,' CEP Discussion Paper No1166, LSE Centre for Economic Performance.

${ }^{1}$ For example, Prime Minister Theresa May on BBC's Andrew Marr show, 17 June 2018.

2 For example, see BBC News, 25 May 2016, 'EU referendum: The politics behind the $£ 350 \mathrm{~m}$ figure.' https://www.bbc.co.uk/news/uk-politics-eu-referendum$\underline{36379061}$ 